\title{
Comparative Analytical Study The Political Dimensions of International Humanitarian Intervention in South Africa - Iraq
}

\author{
Hani Mefleh O. Hamdon \\ Sayel F. Alserhan \\ Al al-Bayt University \\ Al-Mafraq, Jordan
}

\begin{abstract}
The study aimed to clarify the political dimensions of international humanitarian intervention in the fight against the apartheid regime in South Africa, to identify the political dimensions of international humanitarian intervention in the face of the violation of human rights in Iraq, and to highlight international variables and their impact on the adoption of new methods and means of international humanitarian intervention, and the approach of the international system was used in the framework of the theory of systems. The study also used the comparative approach as the study was concerned with comparing international intervention between the two studies in two different periods of time, and the legal approach was used, considering that part of the study was part of international law and international organizations. The study concluded that the cases of humanitarian intervention were linked to the nature of the international system, international interests and the interests of major states, and that there was a correlation between international interests and the identification of political dimensions in international humanitarian intervention in south Africa and Iraq. The impact of international interests has been greatly influenced by the intervention in Iraq as a result of Iraq's natural resources, particularly oil, strategic location and proximity to the Persian Gulf region.
\end{abstract}

Keywords: Political dimensions, international humanitarian intervention.

\section{Introduction:}

The Security Council considers that the policy of apartheid is a threat to the region and therefore to international peace and security. IThis study will attempt to present and compare the situation of internal intervention by examining the political dimensions of international humanitarian intervention in the case of South Africa under the regime. The polar duo and the Iraqi situation under the new international order in 2003.

\section{The importance of the study:}

The importance of the study is highlighted from the scientific and practical point of view:

\section{1- Scientific Importance: Theory:}

The study works to achieve the greatest scientific benefit and enrich the knowledge aspects and support them with one of the topics on the international scene, which is the attention of many researchers, namely international humanitarian intervention in the internal affairs of states, the international community resorted to the use of economic pressures in the case of South Africa while using military force in the Case of Iraq, including knowledge enrichment of the Arab library in an important subject in the field of academic trading and the service of researchers and interested and specialists.

\section{2- Practical importance:}

Highlights from the study's attempt to analyze the role of political dimensions in influencing the operations of humanitarian intervention in the internal affairs of states, and the ability of the major powers in the international system to exploit international circumstances to achieve their objectives and interests, which the researcher will work to highlight by comparing the political dimensions of international humanitarian intervention in the case of South Africa and Iraq.

\section{The objectives of the study:}


This study mainly sheds light on a topic of great importance in the contemporary world due to the many international conflicts and the coordination of the mechanism of the humanitarian intervention process to preserve the human rights that are being attacked, by highlighting the following objectives:

A. To clarify the political dimensions of international humanitarian intervention in the fight against apartheid in South Africa.

B. To identify the political dimensions of international humanitarian intervention in the face of human rights violations in Iraq.

C. To highlight international changes and their impact on new methods and means of international humanitarian intervention.

\section{The problem of the study and its questions:}

There have recently been many international issues and disputes between many countries, whether they are remnants of old wars, disputed border issues, internal conflicts and civil wars that subsequently led to wars, through which the worst methods were used against human rights, prompting many organizations, states and bodies to initiate humanitarian intervention, through which the attempt to preserve human rights came..

Hence the problem of the study in its attempt to analyze the political dimensions that prompted the international community representative of the Security Council to intervene internationally for humanitarian intervention in the fight against the apartheid regime in the case of South Africa, and the violation of human rights in the Iraqi case, and therefore the central question of the research problem was formulated as follows: What effect is the political dimensions of international humanitarian intervention in activating or discouraging the fight against apartheid in South Africa and the violation of human rights in Iraq? This central question is separated from the following sub-questions:

- How effective is the principle of international humanitarian intervention in respect ing human rights and protecting civilians in South Africa and Iraq?

- What is the impact of international changes on new methods and means of international humanitarian intervention that will lead them to success or failure?

\section{Study hypotheses:}

The study is based on a key premise: there is a correlation between international interests and the identification of the political dimensions of international humanitarian intervention in Both South Africa and Iraq.

The study approach: The nature of the subject and the scope of the study and its questions were limited to adopting the principle of systematic integration, as the study can be classified as an analysis of international relations within regional and international frameworks.

\section{The limits of the study:}

Due to the nature of the subject, the researcher did not specify the beginning and end of the period of time of the study. It is looking at comparing the terms and legitimacy of the intervention in South Africa and Iraq in different international circumstances and an international system that has taken a form (bipolar) in the case of South Africa, while in its current period (the new international order) dealt with the issue of its contemporary (Iraq) in the form of an international system different from its predecessor.

\section{Previous studies:}

A number of studies with direct relevance to the subject have been found, and the following is a presentation of the most important of these studies:

1. Amin Makki Madani's study: "International Intervention and Security: Human Rights between Terrorism and Legitimate Defence". This study seeks to address the legitimacy of international intervention and the use of force in accordance with the requirements of international law, which raises questions about international intervention to maintain international peace and security, intervention to protect human rights, and finally international intervention for the purpose of practicing legitimate defense in general, and the link between legitimate defense and what is on the international scene today about armed intervention in the fight against terrorism and the position of the United States and Britain on the recent war on Iraq.

2. The study of Mohamed Ahmed Ali Al-Adawi entitled: "Human security and the human rights system is a study in concepts and mutual relations" this study represents an attempt by the researcher to show the dimensions of the relationship between human security and the human rights system, considering that both concepts raise many 
problems, especially when used in political studies, and the researcher concluded the most important conclusions that the principle of sovereignty is continuous and does not change, but its image, reality and responsibilities change with time or redistribute it. The developments that have now meant the end of the concept of sovereignty, but that sovereignty had changed its concept and had been redistributed.

3. Suleiman Mohamed Khalil Anani's study, "The Darfur Crisis between Politics and International Humanitarian Law", concluded that sudan in the conflict in Darfur has two main laws: international humanitarian law and international human rights law, and from this point of view the researcher relied on two main approaches to analysis of the Darfur crisis from the point of view of international humanitarian law, namely the legal and case study approaches, where the researcher showed the consistency and difference between both variables here (darfur crisis and principles of international humanitarian law).

4. Adil Hamza Othman's study entitled: "The United Nations and the Position of Humanitarian Interventions is a political and legal study". The researcher in this study addresses the position of the United Nations on humanitarian interventions in light of the new international changes that find cover to justify interventions in the affairs of other countries, and try to legitimize this intervention by influencing the United Nations and the Security Council in particular, and concluded that in the American behavior of disarmament in Iraq is a scientific and legal fact that has accompanied it in violations of international law, international humanitarian law and all contemporary international standards as international crimes that require accountability of states and persons involved in their commission, and strangely enough, the United States Department of State's periodic human rights reports did not mention any reference to the crimes committed by American soldiers in Iraq.

\section{5- Kyrre Grimstad : Humanitarian Intervention Historical Legal and Moral Perspectives}

The researcher concludes that allowing intervention in an individual form leads to violation of the principle of sovereignty, and focuses on military humanitarian intervention specifically, and concludes that there is misuse in humanitarian intervention by the major powers, which causes chaos at the international level, which is a matter of concern given the presence of atomic energy that the major powers can think of taking over and using, and therefore it reaches through a discussion of the rule of law to the necessity of the decision of military intervention in the hands of the Security Council, in the hands of the Security Council, in the movement of the countries of the world, and thus it reaches through a discussion of the rule of law to the necessity of the decision of the humanitarian military intervention in the hands of the Security Council, and in the course of the movement of the countries of the world, To face any violations of human rights.

After reviewing previous studies, this study is distinguished from previous studies by attempting to analyse the political dimensions of the cases of international intervention in South Africa and Iraq, while previous studies have focused on one case of international intervention or an analysis of the legal aspects of international intervention.

\section{First: The political dimensions of international humanitarian intervention in South Africa and Iraq}

The decisions of not all international organizations are mandatory, but some of them make their decisions in the form of recommendations of a literary character only, and as we said at the time, that repeating these recommendations in the same subject and circumstances could be transformed into a binding customary rule. Some resolutions by international organizations concerned the protection of human rights, such as those of the Security Council, especially when human rights violations endangered international peace and security, including those of apartheid in South Africa. Such as Resolution 282 of 1970, which recognized the legitimacy of the South African people's struggle for their human rights under the Un Charter and the Universal Declaration of Human Rights (Abu Ala, 2005: 158).

The United Nations General Assembly passed a resolution on 20 November 1963 that the urgent elimination of racial discrimination throughout the world in all its forms and manifestations and to ensure the appreciation and respect of human dignity. The Assembly considers that the distinction between human beings in view of gender, colour or origin is a denial of the principles of the United Nations because it constitutes an obstacle to the friendly and peaceful relations of all'nations and that it would undermine peace and security among peoples. On December 21, 1965, the United Nations adopted an international convention to eliminate all forms of racial discrimination, and the policy of defaming racial discrimination before world public opinion is one of the most effective ways for the United Nations to force governments and peoples to bow to their wishes in this regard, but they can draw the attention of governments and the people to the evils of racial discrimination and the underlying danger and propose ways to eradicate ${ }^{1)}$ it.

( ${ }^{1}$ This is the goal of the International Day for the Eradication of Racial Discrimination, which was first celebrated in 1967. 
The United Nations Subcommittee on the Prevention of Racial Discrimination and The Protection of Minorities, which was formed in 1967, began to examine acts based on non-gender and colour-based prejudices, including religious and political beliefs, and the General Assembly drafted a treaty to eliminate religious intolerance in all its forms at its $1967^{(2)}$ session. The great weakness of the United Nations' efforts to create an operational tool for the protection of human rights and fundamental freedoms is that these efforts are distributed and unrelated, as well as political rather than legal, which has led the United Nations to try to codify these rights by preparing an international charter for civil and political rights, in addition to the Charter of Civil and Political Rights prepared by the United Nations, which has also prepared another international charter, the Charter of Economic, Social and Cultural Rights, each of which will enter into the role of implementation when it ratifies or is ratified. It has 35 states, and the Charter of Civil and Political Rights requires 10 ratifications or approvals until November 1967, and no government ratified or approved either charter, as well as the legal document adopted by the General Assembly at the same time as the previous two charters. This last document is the Optional Protocol to the Charter of International Civil and Political Rights and is detailed in the United Nations Bulletin of 1968 in English, French and Spanish, which undoubtedly has an impact on the elimination of religious intolerance, discrimination and protection. Minorities, if this Charter enters the role of implementation, it will become a legally binding treaty among the states that ratify it.

With the failure of the international protection system for minorities established under the League of Nations and the resulting increase in cases of discrimination and persecution against its children, international jurisprudence after the Second World War tended to believe that the true protection of these rights ... It should not be regulated or nurtured as collective rights, but as rights enjoyed by all individuals and discrimination based on gender, language or religion. In other words, attention is no longer focused on minorities, but rather on human beings wherever they may be, regardless of their ethnic or colour affiliation. The destruction and affront to human rights of the world war was not confined to one country or individual alone (Asfour, 1983: 128).

The United Nations expressed this new direction when it affirmed in its Charter of 1945 and in separate articles $(1,13$, $55,56,62,68,76)$ that human rights must be enjoyed without discrimination.

Despite the success of the international organization in combating discrimination and racial superiority and its condemnation of the policies of racial segregation (apartheid) pursued by some racist regimes such as the former white minority regime in South Africa and the racist regime in Israel, the efforts of the United Nations in implementing or implementing international conventions on respect for human rights The difference stymie was evident during the Cold War between the United States and its Western group, which aimed to affirm civil and political rights for human rights (freedom of opinion, movement and belief... The exclusion and performance of the state from economic life only to a limited extent, and between the Soviet Union and its socialist group and many third world countries, which found that economic and social rights would not be achieved without the presence of the state in every corner of society and tried to define economic and social rights in a way that would impose a commitment on the industrialized countries to give economic aid to third world countries(Nema, 1990:40).

The year 1989 (the year of the end of the cold war) marked the beginning of a new era. The West found its great opportunity in the collapse of the international situation that prevailed throughout the cold war, and interpreted the retreat of the Soviet Union from its global role at the end of the 1980s as a victory for the West's ideas of democracy, pluralism and human rights. It is characterized by the West's isolation of international resolution and hence the control of the United Nations and its use as a tool for its interests.

With regard to internal resistance, the apartheid regime in South Africa was subjected to resistance from blacks who had a history of national struggle dating back to the early years of the twentieth century for their social and political rights. National organizations and political parties were formed and were the main focus of the country's national movement. At the forefront of these movements was the African National Congress (ANC), which led the African struggle against discrimination and apartheid, and since its founding in 1912, the party has waged many political battles and led social organizations against the racist political system. The party was able to ally itself with other powers and was able to hold the People's Congress in 1955, in which it was prodding the Freedom Charter, stressing that

"South Africa belongs to all black and white people living there, and that no government can impose its dominationWeisman, 2001,13). on it unless it depends on the will of the people. It is the people who will govern on the basis of justice, equal rights and equal opportunities. The people must participate in the administration of the country regardless of race and colour.

$\left({ }^{2}\right)$ The United Nations bulletin was published in 1968 in English, French and Spanish entitled "Un and Man - Human Rights Questions and Answers". 
With regard to external pressures, the international community's position was opposed to the policy of apartheid, and the apartheid regime faced a political boycott from most of the world, as well as united nations sanctions, including economic boycotts and numerous resolutions condemning the policy of racial discrimination over the past 30 years. In the 1980s, the crisis of the apartheid regime intensified, international ostracism, boycott and global recession shattered the long record of economic expansion. South Africa faced an economic disaster with numerous setbacks that threatened the interests of investment firms that began to capitalise on the economic situation and instability as a result of the escalating violence in the country (Abd al-Maqdis, 1986:187-188).

Former President Peter Botha understood these situations and tried to make some change to break international isolation and face political chaos and economic decline at home, showing some incomplete political flexibility by announcing in 1982 the implementation of a new constitution for the country that recognizes the existence of legislative councils for people of color and Asians as well as the White House. Botta's attempt has faced internal reactions from whites and blacks to blacks. Some white hardliners left the ranks of the National Party and the Founding of the ConservativeParty, while blacks rejected the constitution, which did not recognize their rights, and insisted on their demands for radical reforms in the political system that guaranteed them their political and social rights and the abolition of the policy of racial discrimination, if Bota failed to make some change, prompted him to resign on August 14, 1989.The trend towards the need for political reforms, an end to apartheid and the preparation for democratic political participation of all society and all races have increased, not only as a result of the struggle of the African people but also by the increased external pressures, particularly those whose effectiveness has begun to take effect (after the end of the cold war and the emergence of new vocabulary for the language of international discourse, such as the inevitability and necessity of the international democratic community. The world is experiencing a historic moment, in which democratic governance has become a subject of global concern, which has led to the emergence of the socalled right to democratic governance (Abdul Rahman, 1977 : 18).

The inevitability of change has convinced the forces that have entrenched the policy of racial discrimination for four decades that it is not in their interest to leave south Africa's future to the forces of black-majority democracy. She therefore took the lead in managing the process of change and realized that remaining out of the process meant marginalizing her political role in the future.

\section{Second: the political dimensions of international humanitarian intervention in Iraq.}

When the United States was able to steer things in the international arena in proportion to its interests, and where objections to its positions and practices have diminished and it can control the course of the international organization's work to serve its interests, it has used the subject of human rights just as it used the fight against terrorism as a pretext to exercise military intervention against this or that country, in addition to intervening in all its forms in order to spread its hegemony to the world as a whole, this process of politicization began early, as it was in the process of disrupting the effectiveness of the two articles (46) and (47) the Charter. The United Nations, which is the only superpower capable of the United Nations, is now subject to the will of this only pole, which is the United States of America, and based on these international changes, we have another concept of humanitarian intervention, which is not necessarily subject to the approval of the United Nations. It takes into account the established principles of general international law and does not adhere to a specific criterion for intervention, what is valid for interference in one country that does not work in another, and intervention can be done individually if it is impossible to obtain international consensus, so that legal norms are replaced by general ethical principles of legislation and authorization of actions up to the point of being considered war crimes (Hans Kochler, $2002: 32$ ).

In the same context, new expressions such as humanitarian warfare and even the use of expressions such as humanitarian bombing to prevent the possibility of conducting an audit of the nature of their actions in the Iraqi case, since August 26, 1992, the date of the ban on Iraqi flights in specific areas, American and British fighter jets are carrying out similar attacks on Iraq, which claim civilians, and this is a special American jurisprudence to implement Security Council Resolution 688, which has not been mentioned from near or far for such action.

The Iraqi government has not rejected this resolution, but it has concluded an agreement with the representative of the UN Secretary-General to secure the access of humanitarian aid guaranteed by Resolution 688, and later approved resolution 986 (1994), known as the oil-for-food resolution, which allowed the import of Iraqi oil for six months, to be placed in a special account in the name of the UN Secretary-General in order to meet humanitarian needs in all regions of Iraq. This decision is tantamount to creating a system that is close to guardianship of Iraq (Kochler, 2002:32) This task of The United States-British intervention is clear, day after day, that it is far from the implementation of the Security Council resolution, but that it comes within the framework of the Strategy of the United States of America to dominat the region and seize its oil, and this policy became completely exposed after the United States declared that its 
goal is to overthrow the Iraqi regime through threats and preparations made in full for large-scale military aggression, which was rejected by the majority of the countries of the world, which contributed to great complications. It is dangerous for the Iraqi crisis, so that the tension in the region and the threat to security and peace in the region is the result of the American intervention and the aggressive intentions of the American administration in particular and israel's exploitation of this atmosphere to carry out large-scale attacks on the Palestinian people and the threat of aggression against other Arab countries, not third: violation of human rights in Iraq or any other pretext.

The United States has sought a number of objectives from its war on Iraq. The first objective of the rest of the objectives is to work to end Iraq's ability to challenge U.S. interests in the region, which include the security of its Gulf allies, ensuring the flow of oil, and ending Iraq's ability to threaten stability in the Middle East in a broad sense, including its sub-region associated with the Arab-Israeli conflict. 10. The united states has been able to use its military presence in the gulf region to carry out its activities in the region. The problem with the United States is that it has failed to develop a successful policy towards Iraq. Over time, the Arab and international arena has become more sympathetic to the tragedy suffered by the people of Iraq. The most serious thing that this policy has led to is that the United States is held responsible for the suffering suffered by the Iraqi people as a result of the embargo imposed on them. This has resulted in the strengthening of Iraq's relations with Arab countries that were part of the international coalition against it, such as Egypt and Syria, as well as some major countries such as Russia, France and China (Abdul Jawad, 2000:158-162).

The united states has been able to provide the necessary support to the united nations. It uses hard-line political discourse and its lack of willingness to give diplomatic and peaceful means a chance when considering the alternatives at its disposal when dealing with what the Administration perceives as a challenge to the wishes of the international community.

The United States policy of striking Iraq is aimed not only at crushing Iraq and deepening the strategic imbalance of power in favor of Israel, but also in order for the U.S. punishment of Iraq to be so severe that it serves as a strong deterrent to the rest of the region and a warning not to attempt to challenge Israel's monopoly on weapons of mass destruction and its uniqueness in the region, and that the decision to impose no-fly zones in northern Iraq on 27 June, June 1991, and in the south on August 27, 1992, is a unilateral decision not taken by the Security Council, and the purpose is, as the director of the Institute for Near Eastern Studies in Washington put it, "if the no-fly zone continues for a long time, the absolute result will be the division of Iraq" (Al-Majzoub, 1998:52-55).

The international humanitarian intervention in Iraq was based on Security Council Resolution 688 of 5 April 1991, which states: "The Security Council is deeply concerned about the repression of the civilian and Iraqi population in many parts of Iraq, which has recently covered Kurdish population areas, led to a large influx of refugees across international borders, and to cross-border incursions that threaten international peace and security in the region, and is deeply disturbed by the grave pain that this entails. The people there condemn the repression of the Iraqi civilian population in many parts of Iraq, which has recently covered Kurdish population areas and threaten international peace and security in the region, and demands that Iraq immediately, as a contribution to the elimination of the threat to international peace and security in the region, immediately stop this repression. The government has also taken a number of measures to ensure that the government's efforts to combat terrorism are not only a matter of concern, but also a clear and effective response to the problem of the use of violence against civilians.

This decision is an important legal precedent in the history of the United Nations on humanitarian intervention, and although it refers in the preamble to article (2/7) of the Charter and affirms the commitment of all Member States to the sovereignty of Iraq and all states of the region, territorial integrity and political independence, he insisted that Iraq allow humanitarian assistance to pass directly and reach all those in need without waiting for the government's approval. Iraq, the first condition of the legitimacy of humanitarian assistance, therefore, before iraq's reaction was known, and on the basis of this resolution,

American, French and British forces were sent to ensure that safe passages were implemented in northern Iraq to provide the Kurds with humanitarian aid, contrary to the requirement of integrity, neutrality and non-discrimination that governs the legitimacy of humanitarian assistance because it singled out the Kurds without the rest of Iraqi society. This decision is therefore a violation of the principle of respect for sovereignty and internal jurisdiction. The United Nations subsequently succeeded in imposing an agreement on Iraq under which it could send 500 of its so-called Blue Guard security forces to replace the Western forces that had previously been sent there to provide humanitarian assistance to the Kurds and to protect UNITED Nations humanitarian personnel working for the United Nations humanitarian programme, UNHCR and other humanitarian organizations. 
The British and French interest in humanitarian intervention in Iraq is due to economic and geostrategic reasons related to oil, the market and international waterways, but France has not renewed its participation in the balance hammer force stationed in southern Turkey, which oversees the implementation of the no-fly zone since December 1996. Humanitarian relief and aid for refugees in northern and southern Iraq, but after the implementation of the resolution resorted to acts of escalation, the Iraqi army tightened its siege on Shiite and Kurdish areas as they were targeted by international protection, leading to widespread disease and poverty among their families until it was lifted in August 1996 when government policy changed (Gali, 1999: 13-14).

Condoleezza Rice, a former Us national security adviser, outlined the administration's justifications for its military intervention in Iraq for purely humanitarian reasons: "This man, Saddam Hussein, is a very evil man. If he leaves his own ways and means, he will destroy his people and neighbours, and if he acquires weapons of mass destruction and the means by which he transfers them to all of us, this represents a very big moral issue that calls for regime change ... If Saddam Hussein is left in power by doing the things he is doing now, it is a threat that will grow and be very much incompatible(Condoleeza Rice, 2002).).

That the United States has explicitly demanded regime change in Iraq in an alleged response to the government's record of political repression, human rights abuses and the use of chemical weapons;

A. Saddam Hussein's dictatorial regime in Iraq lasted 23 years and is one of the most repressive regimes in the world, killing at least 100,000 Iraqis and tortured countlessIraqis.

B. Saddam Hussein's regime launched two aggressive wars against its neighbors Iran in 1983 and Kuwait in 1990, with the resulting large numbers of dead andwounded.

C. This regime used prohibited chemical weapons against Iranian civilians in the south in 1983, and against its Kurdish loyalists in 1988.

D. Between 1992 and 1998, some 100,000 Iraqis living in the marshes between Iraq and Iran were displaced, about 100,000 Kurds were displaced to Iraqi Kurdistan, and all those displaced were displaced or forced to leave their country.

These actions constitute crimes against humanity, war crimes, international crimes of torture, and serious violations of human rights, as part of this policy, building a nation to establish a democratic system, achieving the rule of law and meeting urgent humanitarian needs (Bessioni, 2003:21).

\section{Arguments by supporters of u.S.-British military intervention in Iraq on humanitarian grounds}

The government's policy of "protecting the rights of the population" is a matter of concern.Human Rights Watch, 1999: 22)،

2. The proponents of this theory based their argument on the validity of their doctrine on thefollowing:

(a) Article 1 of the Charter of the United Nations, which makes it a priority for the United Nations to achieve cooperation in resolving international issues of an economic, social and humanitarian nature, to promote and promote respect for the human rights and fundamental freedoms of all people for all people, without discrimination on the basis of gender, language or religion, and to divide men and women (Article 1/3 of the Charter of the United Nations).

(b) The extreme appeal of humanitarian intervention stems from its ability to compensate for the severe disadvantages of human rights, which - to some extent - may fall outside the scope of the work of the Security Council, as evidenced by the genocide in the former Yugoslavia, Somalia and Rwanda.

(a) The united nations is the only countryin the world that has been able toIgnatieff, 2004: 13). achieve the millennium development goal.

\section{Majority arguments opposed to Us-British military intervention in Iraq on humanitarian grounds}

If it is the minority of jurists who have followed the Western trend, who have adopted the principle of militaryhumanitarian intervention, the vast majority of jurists supported by the officials of the institutions concerned mainly on human rights issues see opposition to military-humanitarian intervention, basing on this the illegality of the AmericanBritish invasion of Iraq on this side, and they put forward many arguments in support of theirposition:

1. If humanitarian intervention has the potential to compensate for the severe disadvantages of human rights, which may fall outside the scope of the Security Council's work such as genocide, this is a misperception of the authority of the Security Council: major crises such as the genocide in Rwanda and Bosnia and Herzegovina, for example, have had regional and international implications... The Council is empowered to act under Chapter VII of the Charter, to respond by force - where necessary - as a last resort for maintaining international peace and security, and to support and promote the fundamental objectives of the United Nations, including promoting respect for human rights 
and fundamental freedoms (Article 1/3 of the Charter of the United Nations), and that in historical precedents the Security Council has already intervened militarily in Rwanda, but this intervention has been repeatedly obstructed by permanent members, particularly the United States, the United Kingdom and France (Samantha Power, 202).).

2. The great danger in humanitarian intervention is that it allows individual States to intervene when and where they see an urgent humanitarian necessity, not taking into account the legal limits and controls that have established and govern the use of force, the most important of which is the principle of non-interference in matters that are at the heart of the internal authority of States, and the use of force only under the provisions of collective security in accordance with Chapter VII of the Charter or also under the right to collective or in accordance with article 51 of theCharter.

3. The united nations is the only country in the world that has been able to achieve the millennium development goal..

4. The United States has explicitly demanded regime change in Iraq, in an alleged response to iraq's alleged record of human rights violations, despite the methodology of these disadvantages during the 1980s, when the Iraqi president was actively serving United States interests in the region(Tyler, 2002).) .

This result is not limited to the justification formulated by the United States and Britain; it relates to international humanitarian intervention, but extends to the lie of weapons of mass destruction. These alleged weapons, which were the most telling evidence of the falsehood and falsification of this false claim, in which the Council terminates the mission of the United Nations Monitoring, Verification and Inspection Commission, and Russia abstained from voting on this resolution on the grounds that the Commission established by Resolution 1284 of 1999 did not complete its mission by confirming the existence or denial of the existence of weapons of mass destruction in Iraq, and this decision was the final chapter of this scathing comicdrama.

\section{Fourth: Comparing the political dimensions of international humanitarian intervention in the cases of South Africa and Iraq:}

International attention has shifted from individual interventions to collective interventions on behalf of the United Nations, where the Security Council responsible for human rights issues is counting on the peace maintained during the bipolar system, the depth of internal conflicts resulting from the state crisis that has not succeeded in building stable and effective political institutions. The sovereign state system was therefore subjected to two challenges: first, interdependence, which deprived states of much of their de facto sovereignty, the transfer of many of their functions to the capitalist world economy, and the imposition of restrictions on their internal authority. The government's policy of "protecting the rights of the population" is a major concern for the government. The international community's right to intervene in internal affairs has grown, and it is no longer the core of the state's internal jurisdiction, but is under the control of States and international organizations, at a time when ethnic and religious conflicts and the resulting fragmentation of national entities are spreading, with international chaos leading to further violations of human rights and exacerbating the refugee problem and the problem of famine (Hassanein, 2005:192-193).

The Security Council linked human rights to international security and peace at its 3046 meeting at the level of heads of State and Government for the first time in the history of the Council on 31 December 1992, where the Security Council discussed the item entitled The Responsibilities of the Security Council in maintaining International Peace and Security. International security, where the end of the cold war has brought about a safer, fairer and more humane world, and has made progress in achieving democracy and responsive forms of government, as well as in achieving the purposes of the United Nations, and the removal of apartheid in South Africa will contribute significantly to these positive purposes and trends, including promoting respect for human rights and fundamental freedoms. Members of the Security Council note that the united nations peace-keeping tasks have increased and expanded in recent years. The lack of war and military conflicts between States is not in itself a guarantee of international peace and security, as nonmilitary sources of instability in the economic, social and ecological fields have become a threat to international peace and security, and it is essential that Member States of the United Nations as a whole give a high priority to resolving these issues through appropriate organs" (Security Council, 1993:107-109).

The Berlin Convention, signed by the Countries of the European Cooperation and Security Conference on June 20, 1991, adopted an unprecedented mechanism in international relations through the right of member states to intervene to put an end to any violations of human rights and international laws within a member state. The Helsinki Summit, 7-8 July 1992, succeeded in expanding the concept of European security to include the humanitarian and political dimensions, and decided to form European peace forces under the European Cooperation and Security Conference and are subject to Chapter 8 of the Charter with the aim of maintaining peace in regional conflicts. Because its events and effects are transmitted to other European countries (Moses, 1992:258-260). 
Many calls emerged after the Cold War for increased military interventionby the United Nations to protect human rights and democracy, because such intervention avoids many tragedies when events escalate in a direction that is difficult to control when violence, mass violence and ethnic and religious cleansing occur, especially since the major powers have been able to impose a general trend towards democracy and human rights, which supports the united nations' intervention to protect democratic transition processes in the world, especially since the Security Council has adopted resolutions establishing the security council to establish Peacekeeping forces, to carry out humanitarian missions and to oversee elections in Namibia, Haiti and South Africa and to monitor the human rights situation in El Salvador and Cambodia, all these interventions link world peace with human rights and are based on General Assembly Resolution (46/137) in 1990, which emphasized states' commitment to free and fair elections, and the establishment of an office to assist in the conduct of elections (Hawili, 1994:16).

The link between human rights and international peace and security is not new. During the cold war, the United Nations had already taken many resolutions condemning apartheid policy in South Africa as a threat to international peace and security, but what had emerged in the post-cold-war period was the development and use of tasks specific to United Nations peacekeeping operations that were closely related to many aspects of human rights. The United Nations has supervised elections in dozens of states, both within the framework of peace-keeping operations as part of the political settlements of the crises in these states or at the request of the Governments of the States themselves, and some have considered that these processes pave the way for the right to democratic governance, which entitles citizens to the right to fair elections and international supervision. The United Nations has even participated in providing international cover for a military operation with the aim of restoring Haiti's elected and deposed president of power in his country, and then the Security Council adopted several resolutions under Chapter VII of the Charter to provide military protection for relief convoys in Somalia, Yugoslavia and elsewhere, or to protect minorities, as in Iraq or to establish safe havens and protect them in some internal crises (Useful, 1997 : 50).

The use of the United Nations lends international legitimacy to the practice of intervention in its various forms, including humanitarian intervention, as the statement of the 1992 Security Council summit considered that the issue of human rights could not remain confined to the national borders of States and, as part of the tasks of United Nations preventive diplomacy, regarded as the right to monitor elections, resettle refugees and respect for human rights as tasks associated with the maintenance of international peace and security, as revealed by the Council's practices in subsequent crises by linking the protection of human rights and the requirements of Chapter VII of the Charter. The government's decision to suspend the work of the Security Council is a matter of concern. International attention to the issue of human rights, although it had rightly crystallized after the Second World War and with the establishment of the United Nations, it was pertinent that such attention had its roots in the inter-war period in multiple applications and images.

For example, in addition to the mandate system established within the League of Nations, which was primarily aimed at elevating the population of non-self-governing territories and marching towards independence (Article 22 of the League), there is also the system of international protection for certain communities of individuals, such as the international protection of workers - both national and foreign - within the framework of the Ilo, and there was a system of protection of minorities and foreign privileges intended to protect certain ethnic communities or groups in addition to the protection system.

Diplomacy, which gives States the right to legal intervention, in defence of the interests of their nationals who belong to them in terms of nationality, and in accordance with certain mechanisms and conditions, not to mention the humanitarian intervention that the international community has defined as a means of monitoring the rights of individuals (Fouda, 1964:103).

Whatever the case, the human rights issues of this period were of interest to the internal affairs of states, and at the heart of their internal competence (Nasser al-Din, 2006:18). This is in accordance with traditional international law at the time, so the promulgation of the Charter of the United Nations and the Universal Declaration of Human Rights is the first and the basic building block in universalizing human rights issues and including them among the topics of concern to the international community as a whole. The Charter of the United Nations affirmed the need to strengthen respect for human rights, as the preamble to the Charter stated that the peoples of the United Nations pledged to affirm their belief in fundamental rights and the dignity of the individual and his value for equal rights between men and women (second paragraph of the preamble to the Charter of the United Nations). The Charter paid special attention to these rights by noting that they should be guaranteed and guaranteed without discrimination of gender, national origin, ethnicity, colour or language in at least seven texts and articles (Al-Rashidi, 2003:224). However, despite this census, the Charter did not specify human rights under international protection and did not specify the mechanism to protect 
these rights, which provoked a debate about the legal nature of its texts and articles, between denying the obligation of its texts to lack the question of the definition of rights on the one hand, and because of its lack on the other hand the means of protection, and from the proponents of this trend, jurist Kelsen and jurist Sun Sohn,the organization does not have according to This view isto intervene to ensure respect for human rights, when violated, in one case, concerning the threat to international peace and security, while other jurists, including jurist Jesús Jessub and jurist Latpacht, argued that the Charter was a general principle of international law and therefore of a binding nature with which human rights were at the heart of international affairs(Nasseral-Din, 2006:21-23).

It seems to me at the end of this brief debate about the nature of the Charter, whether it is mandatory on the question of human rights or not, that, despite the validity of the opinion of the first group of jurists, this does not mean that, as another aspect of jurisprudence sees it, the Charter is never the basis for any binding legal value for human rights. The ratification of the Charter by the international community means accepting the mandatory ity of its rules and articles, and thereby adhering to its provisions, as well as the fact that the Charter was subsequently the basis on which many conventions were based. The link to human rights, from the Universal Declaration of Human Rights in 1948, to the 1966 Covenants on Civil and Political Rights and Economic, Social and Cultural Rights, which later formed the socalled International Human Rights Law, to the four Geneva Conventions of 1949 and the 1977 Protocols on international and non-international conflicts, made a quantum leap in promoting respect for human rights in times of armed conflict of all kinds.

In this context, we do not forget to refer to the Convention on the Prohibition and Punishment of Racial Discrimination concluded in 1973, the Convention against Torture and other cruel and inhuman treatment concluded in 1984, in addition to the number of declarations accused of promoting human rights, including: Declaration of the Rights of the Child 1 959, the Declaration of Independence for colonial countries and peoples in 1960, the Declaration of Permanent Sovereignty of States over their natural resources in 1962, the Declaration on the Elimination of All Forms of Discrimination Against Women in 1967(Rashidi, 2003: 225)and other declarations and charters.

The post-World War II era has witnessed an active and sustained movement in the promotion of human rights at the level of the legalization movement as well as at the level of protection mechanisms for these rights, such as the establishment of the Commission on Human Rights by the Economic and Social Council in 1946 in accordance with article 68 of the Charter - now The Human Rights Council is called the Human Rights Council beginning in 2006 - the establishment of the Office of the High Commissioner for Refugees (UNHCR) in 1951, as well as the commissions established by special international agreements to ensure that treaties are implemented and their provisions are respected (CivilPolitical Civil Covenant Human Rights Commission, Article 28, 1966).

\section{Conclusion:}

Humanitarian military intervention must be under THE supervision of the United Nations, but what is actually happening proves that there are still individual or collective interventions by the United States in agreement with their allies, as happened in northern Iraq to create so-called "safe zones" for the Kurds contrary to resolution (688). This is undoubtedly a fundamental lycee of a general current that has begun to emerge in the United States, which tends to be a lack of respect for the Charter of the United Nations and international law, the sovereignty of any country over its resources and its right to independence and self-determination. This trend is all the more serious given that the United Nations, in the absence of international balance, has become a tool in the hands of the United States. The use of international military force is subject to the will and decisions of the United States, and the United Nations has no means of doing so. In the case of Iraq, for example, the Security Council adopted Resolution (688) on 5 April 1991 on the Western U.S. military intervention in northern Iraq. Iraq, on the initiative of France and increased American pressure on the United Nations, with little role for the international organization to reduce its role until it appeared to be a mere front organization, was noted in the international organization's indifference to the deviations made in the implementation of the resolution by the United States and its allies, particularly with regard to the establishment of the southern no-fly zones north of line 36 and south of line 33, where the resolution did not mention the resolution. He also noted the need to preserve the integrity and territorial integrity of Iraq.

While the United States has been divided into three regions or territories by air, hoping to keep it from regaining its regional and international role, there appears to be an overlap between purely humanitarian goals and motives and interventions in the name of humanity to express the self-interests of a state or group of states. The united nations is the only country in the world that has been able to achieve the millennium development goals.

The situation of the international community is not a threat to the security of the region. 
The study suggested a key hypothesis that there is a correlation between international interests and the identification of political dimensions in international humanitarian intervention in Both South Africa and Iraq. The impact of international interests has been greatly influenced by the situation of intervention in Iraq as a result of Iraq's natural resources, particularly oil, strategic location and proximity to the Arab Gulf region, which has led international powers, particularly the United States of America and Britain, to exploit the international instability and weakness of the Security Council to achieve the objectives and interests of these states by exploiting the human rights situation as a justification for interfering in the internal affairs of a Member State of the United Nations, Namely, Iraq.

In the light of the foregoing, it can be concluded that international humanitarian intervention under the pretext of protecting human rights has its roots in the early twentieth century. In the provisions of the Charter of the United Nations and international law that oppose interference in the internal affairs of states and thereby diminish the importance of the concept of state sovereignty.

The study concluded with the following conclusions:

The united nations is the only country in the world that has been able to achieve the goals of the United Nations. The impact of international interests has been greatly influenced by the intervention in Iraq as a result of Iraq's natural resources, particularly oil, strategic location and proximity to the Persian Gulf region.

\section{References:}

\section{Arabic references:}

Abdel Fattah, Shoaib, (1991), Conference on Security and European Cooperation (Helsinki-Paris-Berlin-Prague), International Politics, Cairo: Center for Political and Strategic Studies in The Pyramids, Issue 106, October.

Abdel Rahman, Hamdi, (1997), Multi-Party Elections in Africa, in Dr. Salah Salem Zernoqa et al., Parliamentary Elections in the South, Center for Studies and Research of Developing Countries, Cairo,.

Abdul Jawad, Jamal, (2000), Iraq 1999-2000, in (Gulf Strategic Report 1999-2000), Studies Unit - Gulf Journal, Sharjah, ,

Abu Ala, Ahmed Abdel-Lah Ali, (2005), The Evolution of the Role of the Security Council in International Peacekeeping and Security, Egypt, Law Books,.

Al-Adawi, Mohamed Ahmed,(2011) Human Security and the Human Rights System "A Study in Concepts and Mutual Relations",Security Information Center.

Al-Hawili, Omar, UNITED Nations and Human Rights, The Evolution of Mechanisms, International Politics,(1994), Cairo: Center for Political and Strategic Studies in Al-Ahram, Issue 117, July, p. 16.

Al-Manoufi, Kamal,(1987),Origins of Comparative Political Systems,Kuwait: Al-Rubain Publishing and Distribution.

Al-Rashidi, Ahmed,(2003),Human Rights Comparative Study in Theory and Practice,AlShorouk International Library,.

Anani, Suleiman Mohamed Khalil,(2010),Darfur Crisis between Politics and International Humanitarian Law,Egypt.

Article (1/3) of the Charter of the United Nations.

Asfour, Muhammad,(1983), Arab Human Rights Charter, Arab Future Magazine,Issue (55).

Bessioni, Sharif,(2003), U.S. War in Iraq, Legitimacy of The Use of Force, International Politics Magazine Issue (151), January,..

Fouda, Ezzedine,(1964), International Guarantees of Human Rights, Egyptian Journal of International Law,Volume20,.

Gali, Boutros, five years in Aglass House,Cairo: Al-Ahram Translation and Publishing Center.

Hassanein, Tawfiq Ibrahim,(2005), The Future of The Regime and the State in Iraq and Its Implications for Security and Stability intheGulf, UAE: Gulf Research Center, I2.

Human Rights Commission on the Civil Political Covenant,(1966), Article 28.

Kochler, Hans,(2002), The Concept of Humanitarian Intervention within the Framework of Modern Power Politics, Translation: Khudhair Ahmed Al-Dulaimi, Journal of Political Studies,Issue 8, Year 4, Baghdad.

Located, Bilal Abd,(1986), Recent Violence in South Africa, International Politics Journal,Center for The Study of The Pyramids, Cairo, Issue 83, January.

Madani, Amin Makki,(2009), International Intervention and Security: Human Rights between Terrorism and Legitimate Defence, Arab Journal of Human Rights. 
Moussa, Safaa,(1992), Summit of the Conference on Security and European Cooperation in Helsinki, International Politics, Cairo: Center for Political and Strategic Studies in Al-Ahram, Issue 110, October.

Nafia, Hassan,(1997), Human Rights in the International Organization: The Evolution of the Role and the Limits of Its Effectiveness, Arab Gallery, Cairo Issue E, January.

Nasser al-Din, Nabil Abdel Rahman, (2006)Human Rights Guarantees and Protection, Alexandria,

Nema, Kazem Hashem,(1990),Studies in Strategy and International Politics,Baghdad: House of Public Cultural Affairs.

Osman, Adel Hamza, UNITED Nations and The Position of Humanitarian Interventions, Legal Policy Study, Baghdad: Center for International Studies, 2010.

Security Council,(1993) Official Documents: Security Council Resolutions and Resolutions of 1991, New York: United Nations.

Security Council,(1993), official documents: Resolutions and decisions of the 1992 Council, New York: United Nations.

The mastod, taha.(1998), The Strategic Perspectives and Dimensions of the Gulf Crisis: An American Perspective, AlAhram.

Un Charter Article (13/1) p. 14.

\section{English references:}

Condoleeza Rice,(Aug,15,2002), interview with BBC.

Grimstad, Kyrre,(2001),Humanitarian Intervention Historical Legal and Moral Perspectives, master thesis, university of cape town , cape town .

Human Rights Watch, Report,(1999) On, Kosovo Bombing: Physicians for Human Rights Report. European Journal of International law, 1-22.

Jonathan Weisman,(2001), Mobilization Name Changes, USA, Today, Sept-26,2001-at A 5; Sarah Boxer, Oberation Slick Moniker; Military: Name Game, N.Y. Times, Oct. 13, at A 13.

Michael Ignatieff,(2004), The Year of Leving Dangerously, N. Y. Times Magazine, Mar.14, at 13.

Patric E. Tyler,(2002) Officers Say U.S Aided Iraq in War Despite Use of Gas, New York Times, 17 August.

Power,(2002) Samantha A Problem from Hell: America in the Age of Genocide, Perseus Books,. 